\title{
Common Sharks of Florida
}

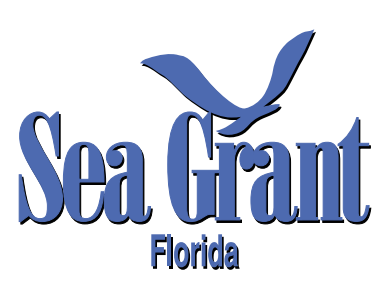

Florida's shark population is diverse and includes species that range in size from only a few feet to more than 40 feet in total length. Experts caution sea-goers to beware of sharks 6 feet or longer due to the damage they can cause in a single bite. Among the species that grow to this size and have been known to attack humans are bull sharks, tiger sharks and great white sharks. However, these are not the predominant shark species that a person is likely to come across in Florida waters. The following species are among the most common.

Blacktip shark (Carcharhinus limbatus) is a shark that bears a distinctive black tip on most fins except its anal fin. Blacktips are principally pelagic but often come inshore in large schools, particularly in association with Spanish mackerel. Frequently it is the most common shark (especially young) in clear-water cuts and along

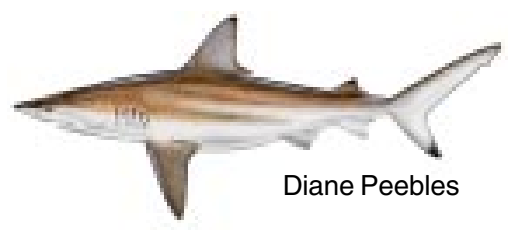
beaches in Florida and the Bahamas. The blacktip is a valuable commercial species with marketable flesh, hide, fins, and liver. It is one of the most commonly collected sharks in the commercial fishery, but is also fished for sport on light tackle and often leaps out of the water when hooked. The blacktip is thought to be the culprit in most "hit and run" attacks on humans. It can grow to 8 feet in length.

Spinner shark (Carcharhinus brevipinna) is a large and slender, fast-swimming shark that often leaps "spinning" out of the water. It feeds primarily on fishes like sardines and herrings but also on small sharks and rays. It is gray-bronze in color with a

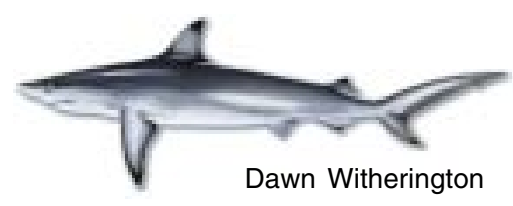
white belly, and is often mistaken for the blacktip shark, but distinguished by the dark tip on its anal fin. Commonly found in coastal waters, it grows to an average of about 6 feet in length.

Sandbar shark(Carcharhinus plumbeus), also called the brown shark, is found nearshore typically at depths ranging from 60 to 200 feet. It is both a predator and scavenger, feeding chiefly near the bottom on fish and shellfish. It migrates long distances and matures at about 6 feet in length but can reach a maximum length of nearly 8 feet. It is brown or gray in color with a

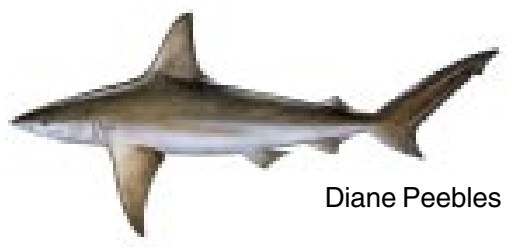
white underside. It migrates south in schools to Florida waters during the winter. Some remain throughout the year. This shark accounts for about 60 percent of the state's commercial landings.

Blacknose shark (Carcharhinus acronotus) is a small shark commonly found in Florida bays and lagoons over sandy, shell and coral bottoms. It has a very noticeable dusky smudge or "moustache" on the tip of its snout, which is more prominent

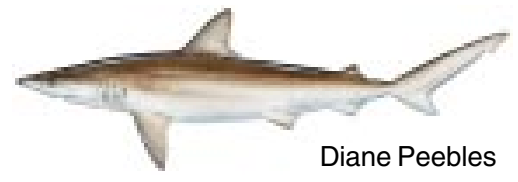
when young. The blacknose feeds on small fishes, but is often preyed upon by larger sharks. Its color ranges from a pale olive-gray above to whitish below. Its maximum length is about 5 feet. While commercially valuable, they pose little threat to humans. 
Nurse shark (Ginglymostoma cirratum) is rusty or yellow-brown in color, and is one of the few sharks that can be found lying on the bottom. It sometimes hides under ledges and wrecks. Nurse sharks

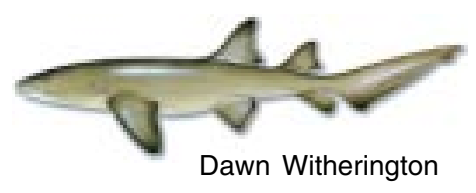
are recognized by fleshy appendages called barbels that hang below the nose and help detect prey. They can grow to 14 feet in length, but most often range from 6-9 feet and weigh an average of 300 pounds. Valued in the Caribbean for its high quality hide, the nurse shark is considered a nuisance species in most North American longline fisheries with fins and meat of little value. Though relatively slow and sluggish, it can be dangerous to humans if aggravated.

Lemon shark (Negaprion brevirostris) is a yellow-gray shark most commonly found in Florida's southern coastal waters, especially around wrecks and ledges. It commonly enters estuarine waters and often ventures into freshwater areas, but does not penetrate as far

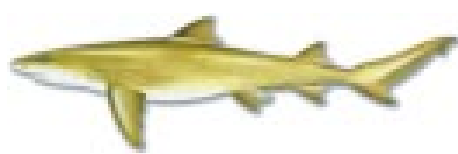

Dawn Witherington up rivers as the bull shark. It eats mainly bony fish but will also eat shrimps, crabs and other small sharks. It can grow to 11 feet, but most do not exceed 9 feet, weighing over 200 pounds. It makes up only a small portion of the commercial shark fishery.

Sharpnose shark (Rhizoprionodon terraenovae) is an inshore species, common in bays and estuaries. Adults occur offshore. This small species, 2 to 4 feet long, is characterized by a long and flattened snout, slender body, a brown to olive-gray body color

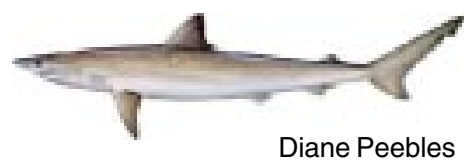
with a white underside, and distinctive small white spots on its back. Adults feed on small fish and crustaceans. Along with the bonnethead, it is the most common shark caught by Florida anglers. While large numbers are taken as bycatch in the U.S. shrimp trawling industry and grouper longline fishery, it is a targeted species that comprises about 30 percent of the total catch in the commercial shark longline fishery.

Scalloped hammerhead shark (Sphyrna lewini) is predatory, feeding mainly on fish, squid, and stingrays. It has a distinctive flattened head extending to hammer-like lobes on each side. It can grow quite large - it is common to 6 feet and can reach 20

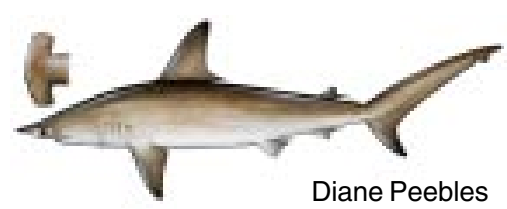
feet. The Florida record is 991 pounds. It is often confused with the much less abundant but larger great hammerhead and can be distinguished from the great hammerhead by the curved backside of its head, which differs from the straight edge found on the great hammerhead.

Bonnethead shark (Sphyrna tiburo) is the smallest of the hammerhead family, commonly 3 to 4 feet in length. It is abundant in nearshore Florida waters, and popular in aquariums. Gray or grayish-brown in color, the bonnethead has a broadly widened

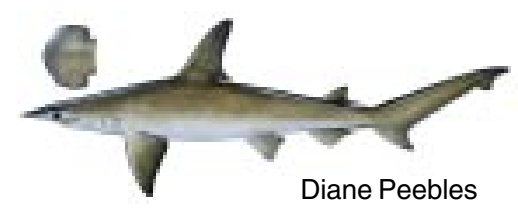
head in the shape of a shovel. It feeds chiefly on crabs and other crustaceans. It is a good sportfish, though of limited commercial value, used mostly as crab bait.

Compiled from: SGEB-25, A Tackle Box Guide to Common Saltwater Fishes of Southwest Florida; Florida Museum of Natural History; NOAA Fisheries; Florida Marine Research Institute; Florida Fish and Wildlife Conservation Commission. Illustrations courtesy of Diane Peebles and Florida Fish and Wildlife Conservation Commission; Dawn Witherington and Vetrol Data Systems, Inc. 